Article

\title{
Who is Teleworking and Where from? Exploring the Main Determinants of Telework in Europe
}

\author{
Purificación López-Igual $[$ and Paula Rodríguez-Modroño * \\ Department of Economics, Pablo de Olavide University, Ctra. de Utrera, Km 1, ES41018 Sevilla, Spain; \\ mplopigu@upo.es \\ * Correspondence: prodmod@upo.es
}

Received: 24 August 2020; Accepted: 20 October 2020; Published: 23 October 2020

check for updates

\begin{abstract}
Telework and ICT-based mobile work (TICTM) arrangements have emerged in response to technological changes driven by digitalisation, increasing flexibility within the labour market, and globalisation. As telework becomes more widespread, these flexible models of work are rapidly expanding to new categories of employees, changing the factors traditionally found to be important for telework eligibility. The aim of this study is to gain a deeper understanding of new profiles of teleworkers, examining main factors that increase or decrease the likelihood of different TICTM arrangements. We apply multinomial logistic regression models to a sample of more than 20,000 workers from the 6th European Working Conditions Survey. Our findings confirm the heterogeneity in the profiles of teleworkers, particularly distinguishing by TICTM arrangement. Occasional teleworkers are usually male managers or professionals, but a relevant percentage of highly mobile teleworkers are technicians and associate professionals, while clerical support workers amount to a large group of home-based teleworkers. The majority of occasional and highly mobile teleworkers are still men, but this can no longer be said of home-based teleworkers. The correlations between telework and permanent contracts, full-time jobs, and living in urban areas are weak, showing that TICTM is spreading into more precarious, temporary, and lower-paid jobs, especially among home-based teleworkers and highly mobile teleworkers.
\end{abstract}

Keywords: telework; ICT-based mobile work; workplace; home-based work; flexible work; work-life balance; digitalization

\section{Introduction}

Telework and ICT-based mobile work (TICTM) arrangements have emerged in response to societal developments, including technological changes driven by globalisation, digitalisation, automation [1], increasing flexibility and precarity within the labour market [2], and increased surveillance [3]. As nowadays a growing number of tasks can be performed and surveilled anywhere and anytime with the help of the new generation of mobile Information and Communication Technologies (ICTs), gradually fewer jobs remain entirely dependent on a single location [4-6]. We draw on recent studies that show how the rapid diffusion of ICT and digitalisation are contributing to the spread of telework to new groups of workers, and many workers with routine and clerical tasks can work remotely $[7,8]$. For instance, it has been estimated that $37 \%$ of jobs in the United States may be entirely performed from home [9].

As labour markets transition to more flexible models of work with digitalisation, working conditions are being completely altered. Previous research has shown that the level of mobility and the intensity of ICT use varies across TICTM arrangements, and it has a significant influence on working conditions [10]. Therefore, this study aims to explore the extent to which the expansion of telework and ICTM practices 
are modifying the dominant or traditional profiles of teleworkers and are rapidly expanding to new categories of workers with different working conditions.

Adapting the definition of TICTM as an ICT-enabled work arrangement characterised by working from more than one place [10], we define teleworkers as employees and self-employed workers who use ICT devices (in particular, smartphones, tablets, laptops, and desktop computers) to perform their work at least 'around $\frac{3}{4}$ of the time', and who work in at least one other location than their employer's premises 'at least several times a month'. We combine work location, level of mobility, and high ICT use to categorise three types of teleworkers according to their different TICTM arrangements $[10,11]$ : regular home-based teleworkers; highly mobile TICTM workers, who frequently work in various places, including from home; and occasional TICTM workers, with mid-to-low mobility and frequency of work outside the employer's premises.

The empirical analysis uses data from the last European Working Conditions Survey (EWCS) conducted in 2015 with more than 20,000 workers in $15 \mathrm{EU}$ countries. This survey is the most recent and comprehensive database on the characteristics and working conditions of European workers. It allows us to distinguish among the different subgroups of teleworkers by TICTM arrangement. Therefore, we can contribute to recent studies on the diversification of the typical profile of the teleworker [12] by including the important distinction of location and intensity of ICT use.

Through several logit and multinomial logit analyses on the determinants of telework, we verify that the profile of the teleworker is diversifying with the expansion of TICTM. In addition, we deepen the analysis of the main characteristics of teleworkers according to their TICTM category. Drawing on literature on the determinants of telework, we have developed seven hypotheses about which workers are likely to telework nowadays and in which telework arrangements these workers are likely to be. Our hypotheses concern the following factors: education level, occupation as a proxy for status within an organisation and the type of task, employment contract, location, gender, family characteristics, and life course. The results show an increasing heterogeneity in the profiles of teleworkers as per workplace and ICT-use intensity, and prove that the TICTM arrangement is a crucial differentiating factor that needs to be taken into consideration when researching and designing public policies on telework.

\section{Literature Review and Conceptual Framework}

\subsection{Concept and Expansion of Telework}

The idea of teleworking was first developed in the 1970s to name a relatively new mode of alternative work arrangements. The term 'telecommuting network' was coined by Nilles to refer to the substitution of the daily commute with the help of ICTs [13-15]. Although there is no universally accepted definition of telework, it is widely accepted that it refers to the organization of work through the use of ICTs.

The practice of employees working remotely, away from the conventional workplace, has become a varied and fast-changing phenomenon [10]. This practice is enabled by the rapid development of ICT available to individuals and employed by organisations [16]. Telework adoption and spread are understood as an evolutionary process represented by 'three generations of telework' - home office, mobile office, and virtual office-with the advance of ICT seen as the main contributor to the development. The concept of TICTM arrangements emerged when the dispersion of mobile devices such as laptops and mobile phones enabled employees to work from practically any location where they needed to work [17].

However, the relative absence of telework in many advanced economies suggests that the extensive spread of affordable and efficient ICT alone does not lead to high telework diffusion [12,18,19]. For instance, Brenke [20] claimed that $40 \%$ of jobs in Germany could technically be transformed by telework, but the telework adoption rate in Germany was only $12 \%$. ICT access should only be seen as a necessary precondition of telework [21], though not a sufficient one. The rapid post-COVID-19 
expansion of telework suggests that the previous slow implantation was not due to a deficit of digital infrastructures.

Other factors such as the individual perception of job suitability, status or power issues, employers' willingness, and organisational aspects are also crucial [22,23]. That a job may be suitable for telework in theory does not mean that the employer will allow the employees to work remotely. There is often scepticism about telework on the part of many employers [24]; it may certainly be demanding to introduce telework, because doing so requires changes in how work is organised and controlled $[25,26]$. However, new technologies are helping organisations monitor, control, and supervise employees while teleworking, which has led to a rapid increase in the gig economy during the last few years. As a result, essential constraining features associated with managers' trust, power, and control have been eased [7,27], facilitating more categories of teleworkers.

Many of the perceived barriers will eventually be cracked by actual telework patterns implemented during the COVID-19 pandemic. While in 2017 only $5 \%$ of the EU working population worked regularly from home, since the outbreak of the pandemic, $37 \%$ of employed people have started working from home [28]. Once telework was imposed in many countries as the priority form of work organisation, firms adapted their organisational processes and discovered the economic advantages of teleworking as regards savings in premises costs, transportation costs, etc. In addition, many workers are also perceiving the benefits associated with the greater autonomy and flexibility in the organisation of their work and family time, and have overcome their fear of losing their rights and status. This shift has been especially rapid in a situation like the current one, characterised by the economic paralysis under the pandemic, in which telework is preventing job loss and spreading into all professional levels and categories. According to a global survey [29], 82\% of the respondents expressed their willingness to telework from home one or more days per week when the COVID-19 crisis is over.

\subsection{Skill, Occupational, and Work-Related Factors}

A vast literature has associated telework with privileged, highly educated, freelance male workers in knowledge-based services and creative industries living in urban areas [8,18,21,30-33]. Many empirical studies show that the university-educated, those employed in what are broadly termed 'advanced services', and high-income earners have usually been more engaged in telework. However, other studies have indicated different categories of teleworkers according to job functions or sectors as early as the 1980s [15,34]. Telework diffusion into precarious and low-status segments of the labour market has accelerated in recent years with new ICTs.

Nowadays, a growing share of employees, but even more markedly self-employed workers, uses ICT to work flexibly on at least an occasional basis [5,6]. According to a recent Eurofound study [11], around $20 \%$ of self-employed workers in the EU are under a TICTM arrangement. Almost half of them are highly mobile, compared to $27 \%$ of employees, and the self-employed tend to use more intensive forms of TICTM than employees.

As regards occupation, TICTM is most common among professionals; $6.5 \%$ of the EU workforce are professionals with a TICTM arrangement. This is followed by technicians and associated professionals ( $4.5 \%$ of the EU workforce) as well as clerical workers and managers (2.5\% of the EU workforce each). Employers are more likely to offer work-at-home options to full-time than part-time employees [35]. However, a somewhat faster growth of telework in sectors other than the advanced services indicates that teleworking arrangements are now diffusing to more traditional parts of the economy [8]. Telework is also expanding among employees with routine tasks that were previously inflexibly tied to the office desk [7]. This trend is assumed to be caused by the employers' demands, expectations, and interests, rather than by the individual workers' own needs and motives, and is related to findings indicating positive effects as regards efficiency, reduced premises costs, reduced absence, and more efficient recruitment of competent staff. Technological innovation and change, the introduction of new work tasks, massive digitalisation of existing work tasks [36], and enhanced monitoring and control at 
a distance are also important drivers [3,7]. Increasing heterogeneity is thus progressively observed with regard to the feasibility of teleworking by occupation [37].

The diffusion of telework to low-skilled jobs implies that the working conditions associated with telework have also deteriorated. While telework was previously deemed suitable only in high-status jobs that enjoy more desirable contracts, afford a high degree of autonomy, are result-oriented, and are in little need of monitoring and control [12], nowadays jobs with a lower status are also considered eligible to be performed remotely or under flexible work arrangements. Gradually, telework is expanding into new professions and employee categories, and more part-time and irregular work arrangements have been added, including new forms of occasional telework [7].

Finally, regarding the location of teleworkers, the literature reflects the prevalence of large urban areas in the practice of teleworking [8]. The reasons provided are diverse. From the supply side, telework has predominantly been an urban or suburban phenomenon [23,38], partly because firms most likely to allow telework are largely concentrated in urban growth centres, and partly because of the wider diffusion of ICT in urban areas. From the demand side, young creative freelancers are usually located in urban areas, and the preference of commuting-based workers for adopting telework is apparently not very strong.

Therefore, we still expect to find a positive relation between telework and the following phenomena: high levels of education, higher-skilled and more qualified jobs, better working conditions, and living in urban areas, though we presume that these relations are losing significance with the expansion of telework and TICTM to lower-skilled and clerical support jobs.

Thus, we define the following hypotheses:

Hypothesis 1 (H1): There is an expansion of different TICTM arrangements to lower-skilled and clerical support jobs.

Hypothesis 2 (H2): There is a positive relation between telework and high levels of education.

Hypothesis 3 (H3): The probability of teleworking is positively related with higher-skilled and more qualified jobs.

Hypothesis 4 (H4): There is a positive relation between telework and better working conditions (permanent and full-time contracts).

Hypothesis $\mathbf{5}$ (H5): Telework is correlated with living in urban areas.

\subsection{Gender Roles and Work-Family Balance}

Traditionally, telework has been associated with male workers, despite an extensive gender literature on the potentialities of home-based teleworking for work-family balance. Because telework enables workers to adapt the place and time of work to their individual needs, many studies report a positive impact of telework, particularly home-based telework, on work-life balance. Parents with children at home rate the family benefits of teleworking higher than those with no children at home [39], and are overrepresented and among the fastest growing groups of teleworkers [8]. Home-based workers may also experience less spillover from work to family life compared with those operating from formal premises, as telework helps reconcile work and domestic and care tasks, particularly for women [39-42]. Since women generally continue doing more household work than their male partners, more of them do regular home-based TICTM in order to combine work and domestic demands [10]. For instance, telework allows mothers to maintain their working hours after childbirth [43], to plan their work and family time [44], and to remain in human-capital-intensive jobs in times of high family demand [45].

These positive effects of telework, particularly of home-based telework, are contested by other studies that highlight its negative implications, such as long working hours and increased stress when family and care work demands coincide with job deadlines. While digitalisation creates new 
flexibility in terms of home and teleworking, the boundaries between work and leisure continue to dissolve. Scheduling flexibility and the blurring of home-work boundaries should not be regarded as intrinsically positive [46]. Without a dedicated workspace, it is hard to partition the two on both a practical and a physical basis, resulting in an overload of domestic work ultimately assumed by women, together with long working hours [47], and further difficulties in balancing work and family life $[48,49]$. In addition, men and women use flexible working in different ways that lead to different outcomes for wellbeing, work-life balance, and work intensification [50]. Therefore, working at home may not actually improve the quality of women's working life, but rather reinforce traditional gender roles [41,51-53]. Indeed, the latest data from the 2015 EWCS show that over $\frac{1}{4}$ of all those working remotely have children under 12 , with $22 \%$ of this large group reporting that they struggle much more than other groups to concentrate on work and achieve an adequate work-life balance [11].

However, recent studies show that male teleworkers are becoming more involved in household issues, which might reduce the existing gender segregation [54]. New evidence on platform workers in Europe also shows that male workers are more likely to live in households with dependent children, and even be responsible for those children, than the general population $[55,56]$.

Thus, the few studies published on the impact of telework under the COVID-19 pandemic $[57,58]$ indicate the existence of a twofold trend concerning gender roles and the distribution of care work according to the family model. On the one hand, it has been observed that the increase in care work produced by this crisis has been mainly taken on by women and, consequently, pre-existing gender inequalities have also increased. On the other, the necessary redistribution of domestic tasks during lockdown may have fostered/accelerated the equalization of gender roles, which might last in the long term.

Consequently, as the last two hypotheses in our study, we postulate that work-life balance constraints lead to the following hypotheses:

Hypothesis 6 (H6): Women are underrepresented among teleworkers, especially among highly mobile and occasional workers, while the percentage of women among home-based teleworkers is higher.

Hypothesis 7 (H7): Only in the case of home-based telework, the probability of teleworking is positively associated with having children and living with a partner, and to a greater extent among women.

We also expect these associations and gender inequalities to be weakening due to the evolution in gender roles and gender equality policies implemented in these countries in the last decades.

\section{Data and Method}

\subsection{Sample}

For the purpose of this study, and with the aim of characterising teleworkers and ICT-based mobile workers in contrast with 'traditional' workers across the European Union, we used the sixth wave of the EWCS, carried out in 2015 by Eurofound. We used a sample that includes 21,761 face-to-face interviews with workers (both employees and self-employed) in the EU15 area (Austria, Belgium, Denmark, Finland, France, Germany, Greece, Ireland, Italy, Luxembourg, Netherlands, Portugal, Spain, Sweden, and the United Kingdom). The choice of this area was made based on the representativeness of teleworkers, since these 15 countries account for $77.6 \%$ of the total sample of the EWCS.

Although telework is not directly addressed in it, this survey does include several questions about ICT use (intensity and frequency) for work outside the employer's premises and about the work location (home, clients' premises, public space, etc.), which allows us to construct different telework categories. 


\subsection{Outcome (Dependent) Variables}

In order to analyse teleworkers versus traditional workers, we define a discrete dichotomous dummy variable, telework (Y), which takes the value 1 if the individual works with ICT devices at least around $\frac{3}{4}$ of the time, and works at one or more other locations than the employer's premises at least several times a month (at the client's premises, in a car or another vehicle, at an outside site, at home, or in a public space). Otherwise, the variable $Y$ takes the value 0.

With regard to the different categories of TICTM workers, the following groups were identified: (a) regular home-based teleworkers are those who use ICT devices at least several times a month to work from home, and at all other locations (except the employer's premises) less often than several times a month; (b) highly mobile teleworkers are those who work with the help of ICT devices at least several times a week in at least two locations other than the employer's premises, or work daily in at least one other location; (c) occasional teleworkers are those working primarily at the employer's premises but occasionally (less than several times a month) work from home or at other locations (less frequently and/or at fewer locations). As discussed in the previous section, these distinctions are made because we presume that different levels of TICTM intensity and the range of places at which individuals work are correlated with different sociodemographic factors and working conditions.

\subsection{Independent Variables}

The introduction of independent variables is based on previous research, which has shown that demographic characteristics such as gender, age, educational level, living with a partner, the presence of children under 15, or living in a rural area are significantly related to teleworking. We also include various employment-related characteristics, such as occupational level (International Standard Classification of Occupations (ISCO)), employment status, working part-time, and years of experience. The definitions of all the independent variables are found in Table A1 (Appendix A).

Table 1 shows the descriptive statistics on the sample (all frequencies weighted). Approximately 1 in $5(18.1 \%)$ of the workers in the EU15 have TICTM arrangements at work. Within the different types of TICTM workers, the majority are highly mobile teleworkers ( $42.9 \%)$, followed by occasional teleworkers $(32.6 \%)$, and, lastly, regular home-based teleworkers (24.4\%). In the sample, teleworkers present differential characteristics with respect to traditional workers; these characteristics are based on a series of parameters. Regarding gender, men in general are more likely to perform telework than women $(39.1 \%)$. However, women tend to use more regular home-based telework $(52.9 \%)$. By age, there is a greater representation of teleworkers between the ages of 26 and 55. As regards having children and living or not as a couple, it is relevant to highlight that the percentage of teleworkers is higher in these cases.

Table 1. Descriptive statistics on the sample (weighted).

\begin{tabular}{ccccccc}
\hline & Total & $\begin{array}{c}\text { Traditional } \\
\text { Work }\end{array}$ & $\begin{array}{c}\text { Total } \\
\text { Telework }\end{array}$ & $\begin{array}{c}\text { Occasional } \\
\text { Telework }\end{array}$ & $\begin{array}{c}\text { Highly } \\
\text { Mobile } \\
\text { Telework }\end{array}$ & $\begin{array}{c}\text { Home-Based } \\
\text { Telework }\end{array}$ \\
\hline No. of observations & 21,761 & 17,818 & 3943 & 1287 & 1691 & $965(24.5 \%)$ \\
Women & 47.33 & $(81.8 \%)$ & $(18.1 \%)$ & $(32.6 \%)$ & $(42.9 \%)$ & 52.89 \\
Age & 42.83 & 42.01 & 39.06 & 40.41 & 30.51 & 43.73 \\
16-25 & 9.65 & 10.53 & 43.17 & 42.64 & 43.30 & 3.48 \\
$26-35$ & 20.88 & 20.45 & 22.34 & 5.81 & 5.95 & 23.79 \\
$36-45$ & 25.33 & 24.66 & 28.64 & 24.62 & 21.18 & 28.56 \\
$46-55$ & 27.34 & 27.21 & 27.95 & 25.30 & 29.13 & 11.39 \\
$56-65$ & 14.27 & 14.58 & 12.80 & 15.00 & 11.73 & 3.16 \\
\hline 65 & 2.53 & 2.57 & 2.30 & 1.14 & 2.80 & \\
\hline
\end{tabular}

Source: Own elaboration based on EWCS 2015 data. 
Table 1. Cont.

\begin{tabular}{|c|c|c|c|c|c|c|}
\hline & Total & $\begin{array}{c}\text { Traditional } \\
\text { Work }\end{array}$ & $\begin{array}{c}\text { Total } \\
\text { Telework }\end{array}$ & $\begin{array}{l}\text { Occasional } \\
\text { Telework }\end{array}$ & $\begin{array}{c}\text { Highly } \\
\text { Mobile } \\
\text { Telework }\end{array}$ & $\begin{array}{c}\text { Home-Based } \\
\text { Telework }\end{array}$ \\
\hline \multicolumn{7}{|l|}{ Level of education } \\
\hline Low $(0-2)$ & 19.42 & 21.93 & 7.18 & 4.45 & 11.27 & 3.82 \\
\hline Medium (3-4) & 48.06 & 51.70 & 30.23 & 31.81 & 34.02 & 20.74 \\
\hline High (5-8) & 32.52 & 26.37 & 62.59 & 63.74 & 54.71 & 75.45 \\
\hline With partner & 67.89 & 66.87 & 72.92 & 71.67 & 72.13 & 76.31 \\
\hline \multicolumn{7}{|l|}{ No. of children $<15$} \\
\hline 0 children & 69.82 & 70.84 & 64.80 & 66.89 & 65.20 & 60.84 \\
\hline 1 child & 15.46 & 15.40 & 15.74 & 15.41 & 14.91 & 17.80 \\
\hline 2 children & 11.89 & 11.18 & 15.41 & 13.62 & 16.06 & 16.97 \\
\hline 3 or more & 2.83 & 2.58 & 4.05 & 4.09 & 3.84 & 4.38 \\
\hline \multicolumn{7}{|l|}{ Employment status } \\
\hline Employee & 82.99 & 85.92 & 77.85 & 80.20 & 74.96 & 79.60 \\
\hline Self-employed & 17.01 & 14.08 & 22.15 & 19.80 & 25.04 & 20.40 \\
\hline Part-time job & 23.76 & 25.56 & 14.96 & 13.36 & 13.58 & 20.02 \\
\hline Rural area & 23.88 & 24.62 & 20.28 & 19.55 & 20.46 & 21.10 \\
\hline Years of experience & 10.57 & 10.57 & 10.55 & 10.66 & 10.42 & 10.63 \\
\hline 1 year & 17.93 & 18.47 & 15.31 & 12.55 & 17.30 & 15.84 \\
\hline $2-5$ years & 25.74 & 25.61 & 26.38 & 27.05 & 26.01 & 26.06 \\
\hline 6-15 years & 31.36 & 31.11 & 32.58 & 33.52 & 31.32 & 33.47 \\
\hline $16-25$ years & 15.12 & 14.83 & 16.54 & 18.11 & 16.27 & 14.64 \\
\hline 26-35 years & 7.50 & 7.48 & 7.60 & 7.86 & 7.50 & 7.39 \\
\hline$>35$ years & 2.35 & 2.51 & 1.59 & 0.91 & 1.60 & 2.60 \\
\hline \multicolumn{7}{|l|}{ Occupation (ISCO) } \\
\hline Managers & 5.57 & 4.14 & 12.56 & 14.01 & 11.48 & 12.30 \\
\hline Professionals & 19.21 & 15.14 & 39.18 & 41.51 & 28.20 & 56.00 \\
\hline $\begin{array}{l}\text { Technicians \& assoc. } \\
\text { professionals }\end{array}$ & 15.44 & 13.72 & 23.90 & 24.38 & 27.84 & 15.82 \\
\hline $\begin{array}{l}\text { Clerical support } \\
\text { workers }\end{array}$ & 10.79 & 11.32 & 8.22 & 8.48 & 6.08 & 11.78 \\
\hline Others & 48.98 & 55.68 & 16.15 & 11.61 & 26.40 & 4.09 \\
\hline
\end{tabular}

Source: Own elaboration based on EWCS 2015 data.

On the other hand, there is a greater presence of teleworkers at higher educational levels, with almost 2 out of 3 having completed high studies (62.6\%). Moreover, there is a greater presence of teleworkers among the self-employed. As regards experience, there do not seem to be significant differences, and regarding the duration of the contract, part-time workers are less represented among teleworkers, particularly in highly mobile and occasional telework. Regarding the spatial distribution across the territory, the telework rate is lower in rural areas.

When we analyse the workers' occupations, it is clear that the distribution is very different between those who telework and those who do not. Professionals are most common among TICTM workers (39.2\%), followed by technicians and associated professionals $(23.9 \%)$, managers (12.6\%), and clerical support workers $(8.2 \%)$. Within the different types of TICTM workers, most regular home-based teleworkers (56.0\%) are professionals, who also are well represented in occasional telework $(41.5 \%)$.

\subsection{Methods of Analysis}

In the first stage, we used binary logistic regression models to analyse the differences between teleworkers and those doing traditional work, as well as to detect the characteristics of the different TICTM workers. In the second stage of the analysis, multinomial logistic regression models were employed to detect differences between the three types of teleworkers depending on their workplace, the level of mobility, and ICT-use intensity. Weighting procedures were used. 


\section{Results}

\subsection{Determinants of Telework}

This section describes the main results obtained from the implementation of the binary logit models on the probabilities of teleworking. Table 2 reflects the marginal effects of three versions of a binary logit model in which the dependent variable is a discrete choice variable that compares teleworkers with those with traditional employment arrangements. These three versions include various regressors for the purpose of testing the robustness of the effects identified. The first model includes the worker's years of experience with the current employer; the second one dismisses this variable as non-significant, and slightly increases the percentage of correctly classified values. The third model incorporates the occupational category, thus increasing $\mathrm{R}^{2}$. The marginal effects and z-statistics associated with each estimated marginal effect are presented in the two columns of each model, showing the significance of the marginal effects. The first row shows the predicted probability of teleworking, which is $18 \%$ for all three models. The interpretation of the marginal effect of the regressors depends on this probability. For instance, being a woman reduces the probability of teleworking by $25 \%(4.6 / 18.45)$ in Model I, and by 32\% in Model III (5.8/18.25), thus confirming H6.

Table 2. Logit models (weighted).

\begin{tabular}{|c|c|c|c|c|c|c|}
\hline & \multicolumn{2}{|c|}{ Model I } & \multicolumn{2}{|c|}{ Model II } & \multicolumn{2}{|c|}{ Model III } \\
\hline & $\begin{array}{l}\text { Marg. } \\
\text { Effects }\end{array}$ & $\mathbf{z}$ & $\begin{array}{l}\text { Marg. } \\
\text { Effects }\end{array}$ & $\mathbf{z}$ & $\begin{array}{l}\text { Marg. } \\
\text { Effects }\end{array}$ & $\mathbf{Z}$ \\
\hline Predicted Probability & \multicolumn{2}{|c|}{0.1845} & \multicolumn{2}{|c|}{0.1827} & \multicolumn{2}{|c|}{0.1825} \\
\hline $\begin{array}{l}\text { Women } \\
\text { Age }\end{array}$ & -0.0466 & $-5.95^{* * *}$ & -0.0477 & $-6.15^{* * *}$ & -0.0589 & $-7.80^{* * *}$ \\
\hline $26-35$ & 0.0526 & $3.45^{* * *}$ & 0.0491 & $3.12^{* * *}$ & 0.0390 & $2.37^{*}$ \\
\hline $36-45$ & 0.0542 & $3.52 * * *$ & 0.0472 & $3.05 * * *$ & 0.0309 & 1.91 \\
\hline $46-55$ & 0.0624 & $3.99^{* * *}$ & 0.0544 & $3.61 * * *$ & 0.0351 & $2.22 *$ \\
\hline $56-65$ & 0.0549 & $3.24^{* * *}$ & 0.0397 & $2.46^{*}$ & 0.0155 & 0.94 \\
\hline$>65$ & 0.0803 & $2.36^{* *}$ & 0.0559 & 1.82 & 0.0284 & 0.98 \\
\hline \multicolumn{7}{|l|}{ Education } \\
\hline Medium (3-4) & 0.0456 & $5.85^{* * *}$ & 0.0458 & $5.96^{* * *}$ & 0.0286 & $2.74^{* * *}$ \\
\hline High (5-8) & 0.2569 & $24.31^{* * *}$ & 0.2580 & $24.62^{* * *}$ & 0.1302 & $10.06^{* * *}$ \\
\hline With partner & 0.0119 & 1.36 & 0.0120 & 1.38 & 0.0077 & 0.93 \\
\hline \multicolumn{7}{|l|}{ No. children $<15$} \\
\hline 1 child & 0.0037 & 0.34 & 0.0030 & 0.28 & 0.0049 & 0.47 \\
\hline 2 children & 0.0312 & $2.34 *$ & 0.0302 & $2.29 *$ & 0.0304 & $2.37 *$ \\
\hline \multicolumn{7}{|l|}{ Status } \\
\hline Self-employed & 0.0817 & $6.95^{* * *}$ & 0.0779 & $6.79 * * *$ & 0.0704 & $6.32 * * *$ \\
\hline Part-time job & -0.0657 & $-6.37^{* * *}$ & -0.0632 & $-6.29 * * *$ & -0.0499 & $-5.11^{* * *}$ \\
\hline \multicolumn{7}{|l|}{ Experience } \\
\hline 2-5 years & 0.0014 & 0.11 & & & & \\
\hline $6-15$ years & -0.0084 & -0.69 & & & & \\
\hline $16-25$ years & -0.0068 & -0.46 & & & & \\
\hline 26-35 years & -0.0144 & -0.80 & & & & \\
\hline$>35$ years & -0.0519 & $-2.33 *$ & & & & \\
\hline \multicolumn{7}{|l|}{ Occupation (ISCO) } \\
\hline Managers & & & & & 0.2336 & $12.12^{* * *}$ \\
\hline Professionals & & & & & 0.1951 & $15.04^{* * *}$ \\
\hline $\begin{array}{l}\text { Technicians \& assoc. } \\
\text { professionals }\end{array}$ & & & & & 0.1775 & $14.68^{* * *}$ \\
\hline Clerical support & & & & & 0.0891 & $6.76^{* * *}$ \\
\hline \multicolumn{7}{|l|}{ Model statistics } \\
\hline $\mathrm{N}$ & \multicolumn{2}{|c|}{21,122} & \multicolumn{2}{|c|}{21,435} & \multicolumn{2}{|c|}{21,408} \\
\hline$\%$ correct & \multicolumn{2}{|c|}{$81.69 \%$} & \multicolumn{2}{|c|}{$81.76 \%$} & \multicolumn{2}{|c|}{$82.25 \%$} \\
\hline Cox \& Snell $\mathrm{R}^{2}$ & \multicolumn{2}{|c|}{0.1067} & \multicolumn{2}{|c|}{0.1066} & \multicolumn{2}{|c|}{0.1512} \\
\hline Nagelkerke $\mathrm{R}^{2}$ & \multicolumn{2}{|c|}{0.1733} & \multicolumn{2}{|c|}{0.1737} & \multicolumn{2}{|c|}{0.2465} \\
\hline
\end{tabular}


Table 2 omits some other tests we performed with other variables and the interaction among them. Those tests allowed for calculating the effect of some of the variables considered for certain groups, such as having a permanent contract, or the interaction between being a woman and having children under 15, or between not having a partner and having children. The results, however, did not improve the model.

Those reflected in Table 2 confirm the hypotheses that both education level and employment status strongly condition the probability of opting to telework. Higher educational levels, with respect to the basic level taken as a reference, significantly increase the probability of teleworking, which is 139\% in Model 1 (25.7/18.45) and 71\% in Model III (13.0/18.24). These results clearly support H2.

Higher age groups, when compared with the one taken as a reference (16 to 25 years), increase the probability of teleworking, especially within the 26 to 55 group, but when occupational categories are introduced in Model III, age loses significance.

H3 is confirmed as we observe that the probability of teleworking is positively associated with higher-skilled and more qualified jobs (with a significance level of 99\%). In fact, the probability of teleworking more than doubles $(128 \%$ ) if the worker holds a managerial position or is a professional $(106.9 \%)$, whereas it is approximately $50 \%$ higher $(48.9 \%)$ among clerical support workers. This shows that telework is still less common in lower occupational categories, but is also spreading into more clerical activities (H1).

With regard to the relation between telework and higher quality jobs, we observe that part-time work reduces the probability of teleworking (which is $27.3 \%$ lower in Model III). However, neither having a permanent contract nor having more years of experience with the employer proved to be significant variables when included in the analysis. Therefore, our results support H4, i.e., there is still an association between jobs with better working conditions and the possibility of teleworking, but it is increasingly less relevant (H1).

As for spatial factors, our research supports H5, since the results show that the probability of teleworking declines in rural areas-telework is $11 \%$ less likely to be an option in rural areas, according to Models I and II-when compared with urban areas with a higher population density. This correlation appears as less significant in Model III, although it is still negative.

Finally, having children under 15 increases the probability of teleworking only after the second child in all three models analysed. On the other hand, the fact of living with a partner does not seem to determine the probability of teleworking. Thus, for now, we can only partially confirm H7. In the next section, we will analyse how various household characteristics relate to the different telework modalities, since this has a crucial influence on the possibilities of balancing work and family life.

\subsection{Differences by Category of TICTM Arrangement}

Table 3 shows the marginal effects of a multinomial model with the same independent variables used in Model III. The multinomial logit model explores the differences in the profiles of teleworkers according to the type of TICTM arrangement, and compares them to those of traditional workers. The first row in the table presents the predicted probability of teleworking, and shows that, from the $18.2 \%$ probability calculated for Model III, $7.8 \%$ corresponds to highly mobile telework, $5.9 \%$ to occasional telework, and $4.5 \%$ to regular home-based telework. The first result of this analysis is the high heterogeneity of the teleworkers' profiles and characteristics depending on the location in which they develop their activity and on the intensity of such activity. All $p$-values in the Hosmer-Lemeshow tests allow us to conclude that there are no significant differences between observed and predicted probabilities, and that the models are well adjusted. Thus, the percentage of correctly classified predictions is over $80 \%$, as shown in the model statistics at the end of both tables. 
Table 3. Multinomial logit model (weighted).

\begin{tabular}{|c|c|c|c|c|c|c|c|c|}
\hline & \multicolumn{2}{|c|}{ Traditional Work } & \multicolumn{2}{|c|}{ Occasional Telework } & \multicolumn{2}{|c|}{$\begin{array}{c}\text { Highly Mobile } \\
\text { Telework }\end{array}$} & \multicolumn{2}{|c|}{$\begin{array}{c}\text { Home-Based } \\
\text { Telework }\end{array}$} \\
\hline & $\begin{array}{l}\text { Marg. } \\
\text { Effects }\end{array}$ & $\mathbf{z}$ & $\begin{array}{l}\text { Marg. } \\
\text { Effects }\end{array}$ & $\mathbf{z}$ & $\begin{array}{l}\text { Marg. } \\
\text { Effects }\end{array}$ & $\mathbf{z}$ & $\begin{array}{l}\text { Marg. } \\
\text { Effects }\end{array}$ & $\mathbf{z}$ \\
\hline $\begin{array}{l}\text { Predicted } \\
\text { probability }\end{array}$ & \multicolumn{2}{|c|}{0.8175} & \multicolumn{2}{|c|}{0.0595} & \multicolumn{2}{|c|}{0.0783} & \multicolumn{2}{|c|}{0.0447} \\
\hline Women & 0.0601 & $7.79 * * *$ & -0.0185 & $-3.42 * * *$ & -0.0455 & $-7.92 * * *$ & 0.0038 & 1 \\
\hline \multicolumn{9}{|c|}{ Age } \\
\hline $26-35$ & -0.0393 & $-2.4^{* *}$ & 0.0172 & 1.41 & 0.0084 & 0.72 & 0.0137 & $1.82 *$ \\
\hline $36-45$ & -0.0310 & $-1.92 *$ & 0.0106 & 0.91 & 0.0115 & 0.96 & 0.0090 & 1.24 \\
\hline $46-55$ & -0.0355 & $-2.25^{* *}$ & 0.0056 & 0.49 & 0.0135 & 1.17 & 0.0164 & $2.28 * *$ \\
\hline $56-65$ & -0.0162 & -0.98 & 0.0144 & 1.17 & -0.0049 & -0.41 & 0.0067 & 0.9 \\
\hline$>65$ & -0.0291 & -1.01 & -0.0181 & -1.25 & 0.0168 & 0.7 & 0.0304 & $1.78^{*}$ \\
\hline \multicolumn{9}{|c|}{ Level of education } \\
\hline Medium (3-4) & -0.0325 & $-3.12^{* * *}$ & 0.0261 & $3.60 * * *$ & 0.0002 & 0.03 & 0.0062 & 1.25 \\
\hline High (5-8) & -0.1326 & $\underset{* * *}{-10.31}$ & 0.0536 & $6.06^{* * *}$ & 0.0447 & $4.89^{* * *}$ & 0.0343 & $6.02^{* * *}$ \\
\hline With partner & -0.00776 & -0.93 & 0.0012 & 0.21 & 0.0009 & 0.15 & 0.0056 & 1.35 \\
\hline \multicolumn{9}{|c|}{ No. of children $<15$} \\
\hline 1 child & -0.0046 & -0.45 & 0.0001 & 0.01 & -0.0009 & -0.12 & 0.0055 & 0.99 \\
\hline 2 children & -0.0308 & $-2.39 * *$ & 0.0015 & 0.18 & 0.0173 & $1.73 *$ & 0.0120 & $1.70 *$ \\
\hline 3 or more & -0.0580 & $2.56^{* *}$ & 0.0202 & 1.30 & 0.0199 & 1.11 & 0.0179 & 1.30 \\
\hline \multicolumn{9}{|c|}{ Employment status } \\
\hline Self-employed & -0.0698 & $-6.28 * * *$ & 0.0159 & $2.05^{* *}$ & 0.0409 & $4.79 * * *$ & 0.0131 & $2.28^{* *}$ \\
\hline Part-time job & 0.0507 & $5.08^{* * *}$ & -0.0229 & $-3.17^{* *}$ & -0.0235 & $-3.03 * *$ & -0.0043 & -0.92 \\
\hline Rural area & 0.0123 & 1.41 & -0.0040 & -0.63 & -0.0093 & 1.47 & 0.0010 & 0.22 \\
\hline \multicolumn{9}{|c|}{ Occupation (ISCO) } \\
\hline Managers & -0.2366 & -12.23 & 0.1074 & $7.80^{* * *}$ & 0.0684 & $5.29 * * *$ & 0.0608 & $6.89^{* * *}$ \\
\hline Professionals & -0.1926 & $-\underset{* * *}{14.88}$ & 0.0815 & $8.68^{* * *}$ & 0.0391 & $4.87^{* * *}$ & 0.0720 & $10.80^{* * *}$ \\
\hline $\begin{array}{l}\text { Technicians \& } \\
\text { assoc. prof. }\end{array}$ & -0.1791 & $-\underset{* * *}{-14.83}$ & 0.0675 & $8.71^{* * *}$ & 0.0798 & $8.40^{* * *}$ & 0.0317 & $6.58^{* * *}$ \\
\hline $\begin{array}{l}\text { Clerical } \\
\text { support } \\
\text { workers }\end{array}$ & -0.0883 & $-6.71^{* * *}$ & 0.0367 & $4.34^{* * *}$ & 0.0086 & $0.93^{* *}$ & 0.0429 & $6.86^{* * *}$ \\
\hline \multicolumn{9}{|c|}{ Model statistics } \\
\hline $\mathrm{N}$ & \multicolumn{8}{|c|}{21,408} \\
\hline$\%$ correct & \multicolumn{8}{|c|}{$81.70 \%$} \\
\hline Cox \& Snell $\mathrm{R}^{2}$ & \multicolumn{8}{|c|}{$\begin{array}{l}0.1719 \\
0.2327\end{array}$} \\
\hline Nagelkerke $\mathrm{R}^{2}$ & \multicolumn{8}{|c|}{0.2327} \\
\hline
\end{tabular}

Legend: ${ }^{*} p<0.1 ; * *<0.05 ;{ }^{* * *} p<0.01$. Source: Own elaborations based on EWCS 2015 data.

Thus, being an occasional teleworker is strongly related with being a man, with a significance level of $99 \%$. In fact, being a woman reduces the probability of occasionally teleworking by $31 \%$. Having secondary or tertiary education is positively related with this type of telework arrangement. Status within the organisation is another determinant variable for this modality, as observed in Figure 1a,b. Managers and professionals are occupations for which an occasional telework is more common. On the contrary, part-time employees are $38 \%$ less likely to telework on occasion, while self-employed workers are $27 \%$ more likely to. In contrast, age, having children, living with a partner, and living in a rural area are not significantly correlated with occasional teleworking. 


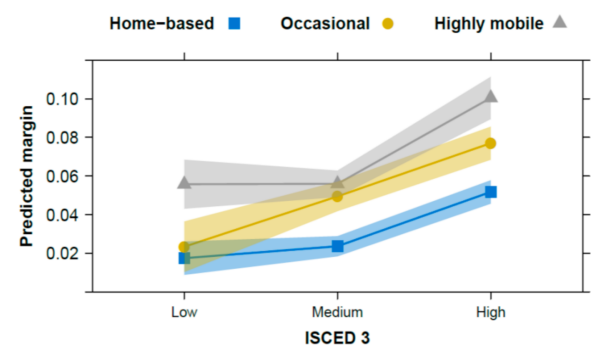

(a)

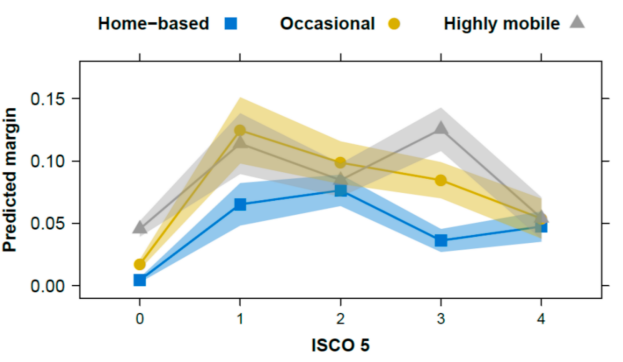

(b)

Figure 1. Predictive margins of Telework and ICT-based mobile work (TICTM) arrangements by (a) level of education and (b) type of occupation, with 95\% confidence intervals. Source: Own elaborations based on EWCS 2015 data.

Highly mobile teleworkers are characterised predominantly as men, in a higher proportion than occasional teleworkers, and as having a university degree, as shown in Figure 1a. The regressors for the occupation variable reveal the high significance of this connection and show that technicians and associate professionals, followed by managers, are the ones more likely to be highly mobile teleworkers. Again, it is less likely for part-time workers to enjoy this type of telework arrangement $(-30 \%)$, although to a lesser extent than with occasional telework. Self-employed workers are $50 \%$ more likely to be highly mobile teleworkers than employees. Having children is positively related with this type of telework arrangement. Workers with two children increase their probability of teleworking by $22 \%$, in contrast with those who have no children. Age, living with a partner, and living in a rural area are not driving factors of performing highly mobile telework.

With respect to regular home-based teleworkers, their profile is very different from the previous ones. Men are not prevalent; in fact, women are the ones most likely to telework from home. Living with a partner has no impact on home-based telework, but having two children under 15 increases the probability of this type of TICTM by $27 \%$. Age is significant in certain age groups, especially for young people under 35, but also for those between 46 and 55 and those over 65 , who are between $30 \%$ and $40 \%$ more likely to telework. Although the probability that workers with tertiary education will work from home is higher, the distribution by level of education is more homogeneous that in the two previous modalities. Something similar happens with occupations: it is still more frequent for professionals (161\%) and managers (136\%) to work from home, but the predicted probabilities are less uneven between categories. For this telework arrangement, no significant correlations with living in a rural area or having a part-time contract were found.

In brief, the division of telework into different modalities according to the location and intensity of ICT use enables a refined analysis of the determinants of telework. We find different profiles of teleworkers according to their TICTM arrangement. Education is still strongly related to telework (H2), but to a lesser extent among occasional teleworkers and home-based teleworkers. The key occupations vary with the type of TICTM arrangement (H3), and having better working conditions (H4) is more frequent among highly mobile and occasional teleworkers than among the home-based ones. Living in urban areas is no longer significantly associated with telework once different arrangements are considered (H5). A higher share of TICTM workers have caring responsibilities than the rest of the workforce (H7). A need to improve work-family balance through telework is observed, especially among home-based teleworkers, who are mostly women (H6), and among highly mobile workers.

\section{Discussion and Conclusions}

This research examines the various profiles of teleworkers, classified into three types: regular home-based teleworkers; highly mobile TICTM workers, who very frequently work in various places; and occasional TICTM workers, with mid-to-low mobility and frequency of work 
outside the employer's premises. This distinction allows us to contribute to a nuanced understanding of the expansion of telework and of the driving factors increasing or decreasing the probability of being eligible for the different TICTM categories.

First of all, our results confirm that, in general terms, the most significant determinants of telework are still self-employment, a higher educational level, and non-manual occupations, especially high-skilled ones. However, other factors, such as age, living in urban areas, higher status, and better working conditions, are losing significance with the strong expansion of telework. As telework becomes more widespread, the factors traditionally found to be important for telework eligibility change, and new groups of workers become eligible $[7,12]$.

Secondly, our analysis identifies different profiles depending on the TICTM arrangement. The new TICTM workers diverge from the profile that was typical until now. A relevant percentage of highly mobile teleworkers are technicians and associate professionals, while clerical support workers make up a large group of home-based teleworkers. The correlations between telework and permanent contracts, full-time jobs, and living in urban areas have also weakened. We can therefore assert that TICTM work is spreading into more precarious, temporary, and lower-paid jobs, especially among home-based teleworkers and highly mobile teleworkers. This ongoing expansion of telework to jobs comprising more routine tasks is transforming its implications and will reduce the autonomy and sense of freedom traditionally associated with it [59].

In summary, this study contributes to a more thorough knowledge of the divergences in teleworking practices and the characterisation of new teleworkers. In a period like the present one, in which the COVID-19 pandemic has unleashed great potential for flexible working [60], and it is highly likely that, in the near future, flexible working will become the norm rather than the exception in many jobs, our contribution can help to avoid telework promotion policies that deepen the gaps and inequalities between various groups of workers. For instance, women are slightly more likely to report having started teleworking during the crisis than men, while pre-COVID-19 teleworking incidence was higher among men [61]. Our study also shows that women are in the majority among home-based teleworkers, more precisely, the TICTM arrangement with a weaker association with high-status jobs. Thus, the opportunities granted by the expansion of telework may have positive consequences for the amelioration of gender inequalities only if appropriate measures are taken in relation to workers' protection and care service provision. As a new working context emerges, addressing the teleworkers' demand for care services will be a key requirement to prevent women from having to take responsibility of a larger share of care work, and to avoid the reproduction of traditional gender roles [62]. Therefore, it is crucial to focus on the impact that the social and economic recovery measures implemented will have on inequalities.

Finally, it is important to note the limitations of this study, which is based on data collected in 2015, i.e., long before the telework expansion following the COVID-19 pandemic. However, these were the most recent data available to carry an in-depth analysis of telework. This limitation calls for further research in this area using updated data.

Author Contributions: Conceptualisation, P.L.-I. and P.R.-M.; data curation, P.L.-I. and P.R.-M.; formal analysis, P.L.-I. and P.R.-M.; writing-reviewing and editing, P.L.-I. and P.R.-M.; funding acquisition, P.R.-M. All authors have read and agreed to the published version of the manuscript.

Funding: This research was funded by CENTRA, grant number PRY074/19, and by the Spanish Ministry of Science and Innovation, grant number PID2019-105835RB-I00. The funders had no role in the design of the study; the collection, analyses, or interpretation of data; the writing of the manuscript; or the decision to publish the results.

Conflicts of Interest: The authors declare that there is no conflict of interest. 


\section{Appendix A}

Table A1. Definition of variables.

\begin{tabular}{|c|c|}
\hline Women & Dummy that takes the value 1 for women and 0 otherwise. \\
\hline Age & $\begin{array}{l}\text { Age declared by respondents, classified in } 6 \text { intervals: } 16-25 \text { years (ref.), } 26-35 \text { years, } \\
36-45 \text { years, } 46-55 \text { years, } 56-65 \text { years, and over } 65 \text { years old. }\end{array}$ \\
\hline & $\begin{array}{l}\text { Highest level of education or training successfully completed declared by } \\
\text { respondents, classified in } 3 \text { intervals: } 1 \text { : low education: ISCED } 0-2 \text {, max. }\end{array}$ \\
\hline Level of education & lower secondary or second stage of basic education; 2 : medium education: \\
\hline & $\begin{array}{l}\text { ISCED 3-4, (upper) secondary education and post-secondary non-tertiary education; } \\
\text { 3: high education: ISCED 5-8, all stages of tertiary education. }\end{array}$ \\
\hline With partner & Dummy that takes the value 1 for individuals who live as a couple and 0 otherwise. \\
\hline No. of children $<15$ & $\begin{array}{l}\text { Number of children under } 15 \text { years old, divided into } 4 \text { groups: without children; } \\
1 \text { child; } 2 \text { children; } 3 \text { or more children. }\end{array}$ \\
\hline Employment status & $\begin{array}{c}\text { Variable that takes value } 1 \text { if the respondent is an employee and } 2 \text { if the respondent is } \\
\text { self-employed. }\end{array}$ \\
\hline Part-time job & Dummy that takes the value 1 for indiv \\
\hline Rural area & $\begin{array}{l}\text { Dummy that takes the value } 1 \text { if the respondent lives in a rural area and } 0 \text { when they } \\
\text { live in an intermediate or urban area, following DEGURBA classification. }\end{array}$ \\
\hline Years of experience & $\begin{array}{l}\text { Years of experience in the current job declared by respondents, classified in } 6 \\
\text { intervals: } 1 \text { year (ref.), } 2-5 \text { years, } 6-15 \text { years, } 16-25 \text { years, } 26-35 \text { years, }>35 \text { years }\end{array}$ \\
\hline ISCO & $\begin{array}{l}\text { The International Standard Classification of Occupation (ISCO), at the 1-digit level, } \\
\text { variable that takes the following values when respondents declare to work: } 1 \text { as } \\
\text { managers; } 2 \text { as professionals; } 3 \text { as technicians and associate professionals; } 4 \text { as clerical } \\
\text { support workers; and a reference value if they have other occupations. }\end{array}$ \\
\hline
\end{tabular}

\section{References}

1. Gschwind, L.; Vargas, O. Telework and its effects in Europe. In Telework in the 21st Century; Messenger, J.C., Ed.; Edward Elgar Publishing: Camberley, UK, 2019; pp. 36-75, ISBN 9781789903751.

2. Standing, G. The Precariat: The New Dangerous Class; Bloomsbury Publishing: London, UK, 2011; Volume 42, ISBN 9781849663526.

3. Sewell, G.; Taskin, L. Out of Sight, Out of Mind in a New World of Work? Autonomy, Control and Spatiotemporal Scaling in Telework. Organ. Stud. 2015, 36, 1507-1529. [CrossRef]

4. Gallouj, F.; Weber, K.M.; Stare, M.; Rubalcaba, L. The futures of the service economy in Europe: A foresight analysis. Technol. Forecast. Soc. Chang. 2015, 94, 80-96. [CrossRef]

5. Holtgrewe, U. New new technologies: The future and the present of work in information and communication technology. New Technol. Work Employ. 2014, 29, 9-24. [CrossRef]

6. Popma, J. The Janus face of the 'New Ways of Work'. Eur. Trade Union Inst. 2013, 44. [CrossRef]

7. Thulin, E.; Vilhelmson, B.; Johansson, M. New telework, time pressure, and time use control in everyday life. Sustainability 2019, 11, 3067. [CrossRef]

8. Vilhelmson, B.; Thulin, E. Who and where are the flexible workers? Exploring the current diffusion of telework in Sweden. New Technol. Work Employ. 2016, 31, 77-96. [CrossRef]

9. Dingel, J.I.; Neiman, B. How many jobs can be done at home? J. Public Econ. 2020, 189. [CrossRef]

10. Eurofound and the International Labour Office. Working Anytime, Anywhere: The Effects on the World of Work; Publications Office of the European Union: Luxembourg; The International Labour Office: Geneva, Switzerland, 2017; ISBN 9789289715683.

11. Eurofound. Telework and ICT-Based Mobile Work: Flexible Working in the Digital Age; Publications Office of the European Union: Luxembourg, 2020; ISBN 9789289720427.

12. Elldér, E. Who is eligible for telework? Exploring the fast-growing acceptance of and ability to telework in Sweden, 2005-2006 to 2011-2014. Soc. Sci. 2019, 8, 200. [CrossRef]

13. Nilles, J.M. Telecommunications and Organizational Decentralization. IEEE Trans. Commun. 1975, 23, $1142-1147$. [CrossRef]

14. Nilles, J.M. Talk is cheaper: And so may be other forms of telecommuting, weighed against the time, energy, and expense of moving oneself. Cities XI IEEE Spectr. 1976, 13, 91-94. [CrossRef] 
15. Pratt, J.H. Home teleworking: A study of its pioneers. Technol. Forecast. Soc. Chang. 1984, 25, 1-14. [CrossRef]

16. Ter Hoeven, C.L.; Van Zoonen, W. Flexible work designs and employee well-being: Examining the effects of resources and demands. New Technol. Work Employ. 2015, 30, 237-255. [CrossRef]

17. Messenger, J.; Gschwind, L. Three generations of Telework: New ICTs and the (R)evolution from Home Office to Virtual Office. New Technol. Work Employ. 2016, 31, 195-208. [CrossRef]

18. Hjorthol, R.J. Teleworking in Some Norwegian Urban Areas-Motives and Transport Effects. Urban Geogr. 2006, 27, 610-627. [CrossRef]

19. Scott, D.M.; Dam, I.; Páez, A.; Wilton, R.D. Investigating the effects of social influence on the choice to telework. Environ. Plan. A 2012, 44, 1016-1031. [CrossRef]

20. Brenke, V.K. Home Office: Möglichkeiten werden bei weitem nicht ausgeschöpft. DIW-Wochenbericht 2016, 83, 95-105.

21. Haddon, L.; Brynin, M. The character of telework and the characteristics of teleworkers. New Technol. Work Employ. 2005, 20, 34-46. [CrossRef]

22. Hynes, M. Telework Isn't Working: A Policy Review. Econ. Soc. Rev. Vol. 2014, 45, 579-602.

23. Pyöriä, P. Managing telework: Risks, fears and rules. Manag. Res. Rev. 2011, 34, 386-399. [CrossRef]

24. Aguilera, A.; Lethiais, V.; Rallet, A.; Proulhac, L. Home-based telework in France: Characteristics, barriers and perspectives. Transp. Res. Part A Policy Pract. 2016, 92, 1-11. [CrossRef]

25. Brodt, T.L.; Verburg, R.M. Managing mobile work-Insights from European practice. New Technol. Work Employ. 2007, 22, 52-65. [CrossRef]

26. Illegems, V.; Verbeke, A.; S’Jegers, R. The organizational context of teleworking implementation. Technol. Forecast. Soc. Chang. 2001, 68, 275-291. [CrossRef]

27. Taskin, L.; Edwards, P. The possibilities and limits of telework in a bureaucratic environment: Lessons from the public sector. New Technol. Work Employ. 2007, 22, 195-207. [CrossRef]

28. Eurofound. Living, Working and COVID-19 First Findings, April 2020; Publications Office of the European Union: Luxembourg, 2020; p. 11.

29. Boogaard, J.; Moller, S. Exploring the Post-COVID-19 Workplace. Colliers International. 2020, p. 6. Available online: https://www2.colliers.com/en-hr/research/exploring-the-post-covid19-workplace (accessed on 20 July 2020).

30. Nätti, J.; Tammelin, M.; Anttila, T.; Ojala, S. Work at home and time use in Finland. New Technol. Work Employ. 2011, 26, 68-77. [CrossRef]

31. Bailey, D.E.; Kurland, N.B. A review of telework research: Findings, new directions, and lessons for the study of modern work. J. Organ. Behav. 2002, 23, 383-400. [CrossRef]

32. Luukinen, A. A profile of Finnish telework: Survey results concerning the nature, extent, and potential of telework in Finland. In Directions of Telework in Finland: Report by the Finnish Experience with Telework Project; Luukinen, A., Ed.; Ministry of Labour, Publication of Labour Administration: Helsinki, Finland, 1996; pp. 1-49.

33. Welz, C.; Wolf, F. Telework in the European Union; European Foundation for the Improvement of Living and Working Conditions (Eurofound): Dublin, Ireland, 2010.

34. Blount, Y. Pondering the Fault Lines of Anywhere Working (Telework, Telecommuting): A Literature Review. Found. Trends Inf. Syst. 2015, 1, 163-276. [CrossRef]

35. Global Workplace Analytics. The 2017 State of Telecommuting in the U.S. Employee Workforce. Available online: https://www.flexjobs.com/2017-State-of-Telecommuting-US (accessed on 20 July 2020).

36. Frey, C.B.; Osborne, M.A. The future of employment: How susceptible are jobs to computerisation? Technol. Forecast. Soc. Chang. 2017, 114, 254-280. [CrossRef]

37. Boell, S.K.; Cecez-Kecmanovic, D.; Campbell, J. Telework paradoxes and practices: The importance of the nature of work. New Technol. Work. Employ. 2016, 31, 114-131. [CrossRef]

38. Vilhelmson, B.; Thulin, E. Is regular work at fixed places fading away? The development of ICT-based and travel-based modes of work in Sweden. Environ. Plan. A 2001, 33, 1015-1029. [CrossRef]

39. Mokhtarian, P.L.; Bagley, M.N.; Salomon, I. The impact of gender, occupation, and presence of children on telecommuting motivations and constraints. J. Am. Soc. Inf. Sci. 1998, 49, 1115-1134. [CrossRef]

40. Hartig, T.; Kylin, C.; Johansson, G. The telework tradeoff: Stress mitigation vs. constrained restoration. Appl. Psychol. 2007, 56, 231-253. [CrossRef]

41. Sullivan, C.; Lewis, S. Home-based Telework, Gender, and the Synchronization of Work and Family: Perspectives of Teleworkers and their Co-residents. Gender Work Organ. 2001, 8, 123-145. [CrossRef] 
42. Walrave, M.; De Bie, M. Teleworking @ Home or Close to Home-Attitudes Towards and Experiences With Homeworking, Mobile Working, Working In Satellite Offices And Telecentres; ESF, Ed.; University of Antwerp: Brussels, Belgium, 2005.

43. Chung, H.; van der Horst, M. Women's employment patterns after childbirth and the perceived access to and use of flexitime and teleworking. Hum. Relat. 2018, 71, 47-72. [CrossRef]

44. Lim, V.; Teo, T. To work or not to work at home: An empirical investigation of factors affecting attitudes towards teleworking. J. Manag. Psychol. 2000, 15, 560-586. [CrossRef]

45. Fuller, S.; Hirsh, C.E. "Family-Friendly" Jobs and Motherhood Pay Penalties: The Impact of Flexible Work Arrangements Across the Educational Spectrum. Work Occup. 2019, 46, 3-44. [CrossRef]

46. Sullivan, C.; Smithson, J. Perspectives of homeworkers and their partners on working flexibility and gender equity. Int. J. Hum. Resour. Manag. 2007, 18, 448-461. [CrossRef]

47. Sullivan, C. Space and the intersection of work and family in homeworking households. Commun. Work Fam. 2000, 3, 185-204. [CrossRef]

48. Golden, T.D.; Veiga, J.F.; Simsek, Z. Telecommuting's differential impact on work-family conflict: Is there no place like home? J. Appl. Psychol. 2006, 91, 1340-1350. [CrossRef]

49. Allen, T.D.; Johnson, R.C.; Kiburz, K.M.; Shockley, K.M. Work-Family Conflict and Flexible Work Arrangements: Deconstructing Flexibility. Pers. Psychol. 2013, 66, 345-376. [CrossRef]

50. Chung, H.; van der Lippe, T. Flexible Working, Work-Life Balance, and Gender Equality: Introduction. Soc. Indic. Res. 2018. [CrossRef] [PubMed]

51. Wellington, A.J. Self-employment: The new solution for balancing family and career? Labour Econ. 2006, 13, 357-386. [CrossRef]

52. Kirkwood, J.; Tootell, B. Is Entrepreneurship the Answer to Achieving Work-Family Balance? J. Manag. Organ. 2008, 14, 285-302. [CrossRef]

53. Lott, Y.; Chung, H. Gender discrepancies in the outcomes of schedule control on overtime hours and income in Germany. Eur. Sociol. Rev. 2016, 32, 752-765. [CrossRef]

54. Giovanis, E. Are Women Happier When Their Spouse is Teleworker? J. Happiness Stud. 2018, 19, 719-754. [CrossRef]

55. Pesole, A.; Urzí Brancati, M.C.; Fernández-Macías, E.; Biagi, F.; González Vázquez, I. Platform Workers in Europe: Evidence from the COLLEEM Survey. JRC Sci. Policy Rep. 2018, 1-65. [CrossRef]

56. Urzì Brancati, C.; Pesole, A.; Fernandez Macias, E. New evidence on platform workers in Europe. JRC Sci. Policy Rep. 2020, 72. [CrossRef]

57. Alon, T.; Doepke, M.; Olmstead-Rumsey, J.; Tertilt, M. The Impact of COVID-19 on Gender Equality. Vascular 2020, 60208, 1708538120930141. [CrossRef]

58. Hupkau, C.; Petrongolo, B. COVID-19 and Gender Gaps: Latest Evidence and Lessons from the UK. Available online: https://voxeu.org/article/covid-19-and-gender-gaps-latest-evidence-and-lessons-uk (accessed on 22 July 2020).

59. Ojala, S.; Nätti, J.; Anttila, T. Informal overtime at home instead of telework: Increase in negative work-family interface. Int. J. Sociol. Soc. Policy 2014, 34, 69-87. [CrossRef]

60. Belzunegui-Eraso, A.; Erro-Garcés, A. Teleworking in the context of the Covid-19 crisis. Sustainability 2020, 12, 3662. [CrossRef]

61. Eurofound COVID-19: Policy responses across Europe. Publ. Off. Eur. Union 2020, 62. [CrossRef]

62. Chung, H. Gender, Flexibility Stigma and the Perceived Negative Consequences of Flexible Working in the UK. In Social Indicators Research; Springer Nature B.V.: Dordrecht, The Netherlands, 2018; pp. 1-25.

Publisher's Note: MDPI stays neutral with regard to jurisdictional claims in published maps and institutional affiliations. 